\title{
Importance of Cephalopod Health and Welfare for the Commercial Sector
}

\author{
Juan M. Vieites, Carlos S. Ruiz, Felicidad Fernández, \\ and Roberto C. Alonso
}

\begin{abstract}
We witness the expansion of cephalopod fisheries and their growing importance in the world's fisheries production. Despite this, only 4 of the 28 taxonomic families are commercially exploited. The rational exploitation of resources could provide large quantities of high-quality cephalopods and would only require further development in harvesting techniques. The intrinsic nutritional value of the cephalopods and the progress of extraction and processing technologies would allow for an expansion of the range of products attractive to consumers, including current non-commercial species. This atlas presents a review of general pathology in octopus, cuttlefish, and squid from different regions of the world. This topic is closely linked to food safety concerns, and it can also be considered a tool for assessing the state of populations. This review provides a resource for teaching and guidance in universities, research centers, public and private laboratories, processing and transformation companies, as well as for administrations in their legislative processes.
\end{abstract}

\section{Keywords}

Cephalopods • Pathology guidance $\cdot$ Seafood $\cdot$ Commercial sector

The 2010 FAO review of cephalopods of the world (Jereb and Roper 2010), considers the existence of 28 families, although the most commercially available species are focused on the families Sepiidae, Loliginidae, Ommastrephidae, and Octopoteuthidae. The number of cephalopod species covered by commercial fishing has continued to grow significantly since 1984, as a result of the increasing market demand and the expansion of fishing activities in new fishing grounds and deeper waters. Species of the Ommastrephidae family are the most important commercial fishery among cephalopods. According to FAO (2016), during the decade from 1997 to 2007, the annual world catch of Ommastrephidae varied

J. M. Vieites $(\bowtie) \cdot$ C. S. Ruiz · F. Fernández · R. C. Alonso ANFACO-CECOPESCA, Ctra. Colexio Universitario, 16, 36310

Vigo, Pontevedra, Spain

e-mail: jvieites@anfaco.es

C. S. Ruiz

e-mail: ffernandez@anfaco.es

F. Fernández

e-mail: cruiz@anfaco.es

R. C. Alonso

e-mail: robertocarlos@anfaco.es between 1 and more than 2 million tons, which represents $50 \%$ of the total catch of cephalopods worldwide. The impressive increase in squid production over the past 30 years is mainly due to the discovery and subsequent exploitation of resources in the southwestern Atlantic, mainly Illex argentinus, as well as an increase in the production of other target species, mainly Dosidicus gigas in the East Pacific and Todarodes pacificus in the Northwest Pacific.

Regarding the evolution of the catches of all cephalopods, Doubleday et al's (2016) data show a general upward trend in the period 1955-2012. Within this general trend, we highlight that, after reaching the maximum level of 4.3 million tons in 2007, the increase in total cephalopod catch slowed for some years. However, in 2012, catches surpassed again and, in 2014, they surpassed 4.5 million tons, according to the 2016 FAO report. In successive reports (FAO 2018), a dramatic drop in the cephalopod catch was recorded in 2016, although there seem to be signs of recovery in 2017. Catches of octopuses (family Octopoteuthidae) have been shown, in global figures to be more stable than those of squids. Since 2008, both catches of cuttlefish and octopuses have remained relatively 
stable between 300 and 350,000 tons, respectively, although this represents a decrease in the case of cuttlefish and an increase in octopuses, as compared to previous years.

From the 2018 FAO report on the state of fisheries and aquaculture, we can mention that, after five years of continuous growth, which began in 2010, catches of cephalopods stabilized in 2015, but fell in 2016, when the three main species of squids recorded a combined loss of 1.2 million tons.

The potential for the fishery of all species of the exploitable Ommastrephidae family is estimated between 6 and 9 million tons. A large number of squids of this family, which lacks ammonium, are considered little exploited. These include Sthenoteuthis pteropus, Ommastrephes bartramii, Martialia hyadesi, Todarodes sagittatus, Sthenoteuthis oualaniensis, Nototodarus philippinensis, Dosidicus gigas, and the circumpolar and subantarctic species Todarodes filippovae.

The assessment of the availability of commercial and other less exploited species faces the difficulties derived from the short life of the cephalopods and their adaptive strategies to ensure survival against stressful environmental conditions, including those caused by intensive fishing. Therefore, both stock assessments and predicting important fluctuations in catches and landings are difficult (Pierce and Guerra 1994; Robert et al. 2010). Barring uncertainties in the assessment of fishing potential, the exploitation of these species could provide large quantities of high-quality cephalopods and would require only further development in harvesting techniques.

On the consumption forecast of products derived from cephalopods, the aforementioned FAO 2018 and 2016 reports show that Spain, Italy, and Japan are the main consumers and importers of these species. Thailand, Spain, China, Argentina, and Peru were the largest exporters of squid and cuttlefish, while Morocco, Mauritania, and China were the main exporters of octopus. Vietnam is expanding its cephalopod markets, including squid, in Southeast Asia. Other Asian countries such as the Republic of Korea and India are also important suppliers. In South America, there is an increasing interest in the Humboldt Squid (Dosidicus gigas), which is being exported from Peru to more than 50 countries, and efforts are being made to develop new products. In 2013, the main markets, especially Japan and the European Union, remained strong, despite the difficult economic situations and the high prices of these species. In the 2014-2015 period, the largest increases in the markets were of octopus, rather than of squid and cuttlefish. However, the reduction in catches resulted in a shortage of supply in 2016 and 2017.

On consumer preferences according to the FAO 2016 report, the use of squid for human consumption is extensive and diverse. There is an increasingly wide range of raw, refrigerated, frozen, dry, canned, and prepared products. Despite the aversion of cultural origin of the inhabitants of northern countries to the consumption of cephalopods, technological development allows to add value to cephalopod products, making them attractive to broader layers of consumers. In one of the last discussion forums (MAFE 2012) it became clear that, currently, consumers consider food as the guarantor of their future health. The high-protein content, the abundance of essential amino acids, and the low-fat content of cephalopods make them an ideal food to be part of healthy and balanced diets. The data collected in nutritional tables such as those prepared by ANFACO-CECOPESCA (2018) and the USDA (2018) show that the squid form a homogeneous group with high-protein content, in which essential amino acids abound (with slight differences in level with respect to octopuses) plus a low-fat content, giving a healthy profile. The significant numbers of authorized declarations of health properties, to which the products derived from cephalopods can be accepted under the provisions of the EU (2012), support the nutritional quality of cephalopods.

From the reports on the state of world fisheries, it should be noted that in the last 40 years the percentage of cephalopods production to world production increased from 2 to around $5 \%$. The manufacturing industry requires constancy in purchases. The important fluctuations experienced by the main species of cephalopods of commercial interest raise practical issues in the control of conformity of the specifications of commercial quality of the raw materials since they condition the specifications of the final products. This entails the execution of a series of controls based on self-control, on the maximum content of certain contaminants and microbiological criteria, and on the organoleptic or sensorial characteristics that determine the acceptability of the raw material.

With this panoramic view it presents, our Atlas covers aspects directly linked to food safety and quality. The Atlas presents an overall review of the general pathology in octopus, cuttlefish, and squid from other regions of the world. Regarding morphological aspects, it describes macro and microscopic lesions and their consequences for organisms, both in the wild and from mariculture. In addition, there is a chapter on tissue and organ regeneration and others on viruses and parasites.

Given the expected future projection of cephalopods in the world diet, the Atlas is considered a reference publication for teaching and guidance in universities, research centers, public and private laboratories, processing and transformation companies, as well as for use by administrations in their legislative processes.

\subsection{Concluding Remarks}

The chapter justifies the importance of cephalopod health and welfare for the commercial sector and the usefulness of the handbook under the panoramic view presented. 


\section{References}

ANFACO-CECOPESCA (2018) IV Forum of Innovation and Technology of Anfaco-Cecopesca: "Innovation and Biotechnology for a more competitive Marine and Food sector" 10.9.2018 (Available in http://www.anfaco.es/es/index.php)

Doubleday ZA, Prowse TA, Arkhipkin A, Pierce GJ, Semmens J, Steer M, Leporati SC, Lourenço S, Quetglas A, Sauer W, Gillanders BM (2016) Global proliferation of cephalopods. Curr Biol 26 (10):406-407. https://doi.org/10.1016/j.cub.2016.04.002

EU (2012) Commission Regulation No 432/2012 of 16 May 2012 establishing a list of permitted health claims made on foods, other than those referring to the reduction of disease risk and to children's development and health (Official Journal of the European Union L 136/1, https://eur-lex.europa.eu/LexUriServ/LexUriServ.do?uri=OJ: L:2012:136:0001:0040:en:PDF

FAO (2016) The state of world fisheries and aquaculture 2016. Contribution to food security and nutrition for all, Rome, p 224

FAO (2018) The state of world fisheries and aquaculture. Fulfilling the objectives of sustainable development, Rome, http://www.fao.org/3/ i9540en/I9540EN.pdf

Jereb P, Roper CFE (2010) Cephalopods of the world: an annotated and illustrated catalogue of cephalopod species known to date. FAO
Species Catalogue for Fishery Purposes 4:1- 4. FIR/Cat. 4/2 ISBN 92-5-105383-9

MAFE (2012) Guide of the nutritional qualities of products from Extractive Fisheries and Aquaculture: risk-Benefit Binomial. Ministry of Agriculture, Food and Environment (Spain), Spain

Pierce GJ, Guerra A (1994) Stock assessment methods used for cephalopod fisheries. Fis Res 21:255-285

Robert M, Faraj A, Mcallister MK, Rivot E (2010) Bayesian state-space modelling of the De Lury depletion model: strengths and limitations of the method, and application to the Moroccan octopus fishery. ICES J Mar Sci 67:1272-1290

USDA (2018) United States Department of Agriculture Agricultural Research Service National Nutrient Database for Standard Reference. Tables available in three web pages: https://ndb.nal.usda.gov/ ndb/foods/show/4641?fgcd=Finfish+and+Shellfish + Products $\&$ manu $=\& l$ facet $=\&$ format $=\&$ count $=\& \max =35 \&$ offset $=$ 140\&sort=\&qlookup; https://ndb.nal.usda.gov/ndb/foods/show/ 4644? fgcd=Finfish+and+Shellfish+Products\&manu=\&lfacet= \&format=\&count=\&max=35\&offset=140\&sort=\&qlookup; https:// ndb.nal.usda.gov/ndb/foods/show/4653?fgcd=Finfish+and + Shellfish+Products\&manu $=\&$ lfacet $=\&$ format $=\&$ count $=\& \max =$ 35 \&offset $=140 \&$ sort $=\&$ qlookup
Open Access This chapter is licensed under the terms of the Creative Commons Attribution 4.0 International License (http:// creativecommons.org/licenses/by/4.0/), which permits use, sharing, adaptation, distribution and reproduction in any medium or format, as long as you give appropriate credit to the original author(s) and the source, provide a link to the Creative Commons licence and indicate if changes were made.
The images or other third party material in this chapter are included in the chapter's Creative Commons licence, unless indicated otherwise in a credit line to the material. If material is not included in the chapter's Creative Commons licence and your intended use is not permitted by statutory regulation or exceeds the permitted use, you will need to obtain permission directly from the copyright holder. 